\title{
PERENCANAAN LANSKAP UNTUK PELESTARIAN KAWASAN WISATA DANAU LIMBOTO, GORONTALO (STUDI KASUS SUB-DAS PAYUNGA) \\ Rizkaf Zulfikar Kasim ${ }^{1}$, Ute Lies Khadijah ${ }^{2}$ Awaludin Nugeraha ${ }^{2}$ \\ ${ }^{1}$ Sekolah Pascasarjana Magister Pariwisata Berkelanjutan, Universitas Padjadjaran, Jl. Dipati Ukur No. 35 \\ Lebakgade, Kecamatan Coblong, Bandung 40132 \\ E-mail: rizkaf.zulfikar@gmail.com
}

\begin{abstract}
ABSTRAK
Danau Limboto merupakan danau besar yang terletak di Kabupaten Gorontalo. Danau dengan luas sekitar 3.000 hektar ini merupakan muara dari lima sungai besar, yakni Sungai Bone Bolango, Sungai Alo, Sungai Daenaa, Sungai Bionga, dan Sungai Molalahu. Danau Limboto memiliki peran penting bagi masyarakat Provinsi Gorontalo khususnya pesisir danau. Beberapa fungsi Danau Limboto antara lain;(1) sumber ekonomi masyarakat pesisir danau, (2) reservoir alami limpasan air dari Daerah Tangkapan Airnya, (3) sumber potensial air bersih, (4) sumber keanekaragaman hayati, dan (5) taman wisata danau. Dengan permasalahan penyusutan dan pendangkalan yang terus terjadi setiap tahunnya akan sangat berpengaruh terhadap suatu ekosistem danau dan sekitarnya. Penelitian ini akan menganalisis daya dukung serta daya tampung dari kawasan sekitar danau limboto dengan pendekatan ekologi guna melestarikan kawasan wisata danau limboto sebagai suatu destinasi yang berkelanjutan. Perencanaan Lanskap untuk pelestarian kawasan wisata danau akan dituangkan dalam penataan lanskap sub-wilayah, yaitu pemukiman, perkebunan/pertanian, dan hutan.
\end{abstract}

Kata kunci; Danau, ekologi, pelestarian

\section{LANDSCAPE PLANNING FOR THE PRESERVATION OF LIMBOTO TOURISM AREA, GORONTALO (CASE STUDY OF PAYUNGA SUB-DAS)}

\begin{abstract}
Lake Limboto is a large lake located in Gorontalo Regency. The lake with an area of around 3,000 hectares is the estuary of five major rivers, namely the Bone Bolango River, Alo River, Daenaa River, Bionga River, and Molalahu River. Lake Limboto has an important role for the people of Gorontalo Province, especially the coastal lakes. Some functions of Lake Limboto include: (1) the economic resources of the lake's coastal community, (2) natural reservoirs of water runoff from their catchment areas, (3) potential sources of clean water, (4) sources of biodiversity, and (5) lake tourism parks. With the problem of shrinkage and silting that continues to occur every year will greatly affect an ecosystem of the lake and its surroundings. This study will analyze the carrying capacity and capacity of the area around Lake Limboto with an ecological approach to preserve the tourism area of Limboto Lake as a sustainable destination. Landscape planning for the preservation of lake tourism areas will be outlined in the arrangement of subregional landscapes, namely settlements, plantations / agriculture, and forests.
\end{abstract}

Keywords: Lake, ecology, conservation

\section{PENDAHULUAN}

Indonesia memiliki ekosistem darat yang menggenang diantaranya adalah danau. Keadaan ekosistem perairan danau tersebut kini cenderung mengalami degradasi karena kurang kepedulian dan kesungguhan profesional dalam pengelolaannya. Banyak diantaranya terancam, baik dari segi kuantitas maupun kualitas airnya, juga dari segi kelangsungan hidup biotanya. Hal ini disebabkan terutama oleh meningkatnya kegiatan manusia di perairan maupun daerah tangkapan airnya.

Danau Limboto merupakan salah satu destinasi wisata danau yang terancam hilang karena penyusutan dan pendangkalan yang terus meningkat tiap tahunnya. Permasalahan yang dihadapi danau limboto diantaranya masalah yang dihadapi adalah pendangkalan dan penyusutan luas, penurunan kualitas air danau, penurunan volume air, banjir, perusakan hutan dan lahan, dan kerusakan hutan riparian. Hal ini akan menjadi fokus utama dalam suatu perencanaan lanskap kawasan wisata danau limboto untuk pelestarian dan pengoptimalan kawasan danau . melalui pendekatan ekologi dan konservasi lanskap pada Kawasan Wisata Danau Limboto akan memberikan peran yang sangat penting dalam melindungi sumberdaya alam serta melestarikan keanekaragaman hayati

Pendekatan yang akan dilakukan yakni melalui suatu pendekatan ekologi dengan metode konservasi tanah dan air . dalam hal ini, penerapan konservasi tanah dan air berkaitan dengan klasifikasi kemampuan lahan . Klasifikasi kemampuan lahan (land capacity clasification) adalah penilaian lahan (komponen- 


\section{PERENCANAAN LANSKAP UNTUK PELESTARIAN KAWASAN WISATA DANAU LIMBOTO, GORONTALO (STUDI KASUS SUB-DAS PAYUNGA) \\ (Rizkaf Zulfikar Kasim, Ute Lies Khadijah, Awaludin Nugeraha)}

komponen lahan) secara sistematik dan pengelompokannya dalam beberapa kategori berdasarkan atas sifat-sifat yang merupakan potensi dan penghambat dalam penggunaannya secara lestari (Arsyad,1989).

Perencanaan lanskap untuk pelestarian Kawasan Wisata Danau Limboto dimaksudkan untuk mendukung upaya konservasi kawasan danau dan pemanfaatan kawasan secara baik dan benar serta dapat menjamin kesejahteraan masyarakat.

\section{METODE}

Metode yang akan digunakan dalam penelitian ini adalah deskriptif kualitatif melalui studi lapang dan studi pustaka. Metode ini dipilih untuk mengungkapkan kejadian atau fakta, keadaan, fenomena, variabel dan keadaan yang terjadi saat penelitian berlangsung dengan menyuguhkan apa yang sebenarnya terjadi. Tahapan yang digunakan dalam penelitian ini mengacu pada Gold (1980) yang telah dimodifikasi yaitu mulai dari tahap persiapan, inventarisasi, analisis, sintesis, konsep perencanaan, dan perencanaan lanskap.

\section{HASIL DAN PEMBAHASAN}

\section{Kondisi Umum}

Sub-DAS payunga berada dalam DAS Limboto yang terletak pada sisi selatan danau limboto, Kecamatan Batudaa dengan luas 4.644 ha. sub-DAS Payunga dimana pada daerah ini terdapat 5 desa yang dilintasi jalan provinsi pada sisi selatan danau limboto dengan jumlah penduduk 27.978 jiwa dengan kepadatan penduduk 602.4 jiwa/km2. Peta Sub-DAS Kabupaten Gorontalo dapat dilihat pada Gambar 4 dan peta administrasi Sub-DAS Payunga terdapat pada Gambar 5. Sub-DAS payunga memiliki batas wilayah sebagai berikut:

a) Sebelah Utara : Danau Limboto

b) Sebelah Timur : Kota Gorontalo

c) Sebelah Selatan: kecamatan batudaa pantai

d) Sebelah Barat : kecamatan tabongo

Berdasarkan data Gorontalo dalam Angka (2012) dari Kecamatan Batudaa memiliki perkerasan/bangunan dengan luas 238,76 Ha. Sub-DAS payunga terdapat 5 desa dengan masing-masing luasan payunga 980 ha, huntu 1350 ha, bua 910 ha, iluta 1025 ha, dembe 650 ha. Sebagian penduduk kecamatan batudaa berprofesi sebagai nelayan dan petani).

\section{Analisis}

\section{Aspek Legal}

Berdasarkan PP No.47 Tahun 1997 tentang Rencana Tata Ruang Wilayah (RTRW) Nasional, kawasan sekitar danau/waduk ditetapkan sebagai kawasan yang masuk dalam kawasan perlindungan setempat (Haeruman, 1999). Kawasan perlindungan setempat diperuntukkan bagi kegiatan pemanfaatan lahan yang dapat menjaga kelestarian jumlah, kualitas dan penyediaan tata air dan kelancaran serta ketertiban pengaturan dan pemanfaatan air dari sumber-sumber air. Berdasarkan peraturan ini maka perlu diperhatikan tentang perlindungan setempat yang terdiri dari garis sempadan sungai dan garis sempadan danau dimana sekitar 250 meter disekitar mata air (Bappeda Provinsi Gorontalo). Berdasarkan RTRW Provinsi Gorontalo nomor 4 tahun 2011 pasal 66, Danau Limboto merupakan kawasan strategis provinsi dari sudut kepentingan daya dukung lingkungan sebagaimana yang dimaksud pasal $62 \mathrm{~d}$. Adapun fungsi yang di maksud dengan kawasan strategis provinsi yakni sebagai alokasi ruang untuk berbagai kegiatan sosial ekonomi masyarakat dan kegiatan pelestarian lingkungan dalam wilayah provinsi yang dinilai mempunyai pengaruh sangat penting terhadap wilayah provinsi bersangkutan.). Sub-DAS payunga yang berada di kecamatan batudaa juga merupakan kawasan peruntukkan pertanian komoditas tanaman pangan dan hortikultura sebagaimana yang tertera pada RTRW provinsi gorontalo pasal 55. Begitupun dengan penentuan kawasan lindung pada bagian hulu DAS yang dijelaskan pada RTRW Provinsi Gorontalo nomor 4 tahun 2011 pada pasal 24 .

\section{Aspek Fisik}

Sub-DAS payunga memiliki kondisi topografi dengan kemiringan lahan yang cukup landai pada sisi utara. Secara spasial sub-DAS Payunga memiliki empat kelas jenis kemiringan, yakni kemiringan dengan persentase $0-18 \%, 8-15 \%, 15-25 \%$ dan 25-40\%. sub-DAS payunga didominasi oleh kemiringan lahan $0-8 \%$ yang berarti cukup landai yang bisa dikembangkan untuk sarana dan prasarana. Pada kemiringan lahan $8-15 \%$ bisa dimanfaatkan untuk lahan pertanian. Pada kemiringan $15-40 \%$ diarahkan untuk menjadi hutan dengan fungsi konservasi. Komponen topografi lainnya adalah elevasi. Berdasarkan peta elevasi dari Bappeda Kabupaten Gorontalo, kecamatan batudaa memiliki ketinggian 10-500 m dpl. Ketinggian atau elevasi kawasan yang terbentuk dari keragaman topografi ini menciptakan view yang menarik sebagai potensi alam yang dimanfaatkan sebagai orientasi di kawasan.Perlu diperhatikan untuk garis sempadan sungai dan danau yang bisa mempengaruhi kenaikan debit air pada musim-musim tertentu . 
Sub-DAS payunga merupakan salah satu daerah dengan tangkapan air yang menghasilkan hasil erosi yang besar yakni 2.18 juta ton/tahun dengan hasil sedimen 0.64 juta ton/tahun dengan Sediment Delivery Ratio (SDR) sebesar $29.28 \%$. Dari jumlah hasil erosi dan sedimen yang besar setiap tahunnya akan berdampak kerusakan kualitas air terhadap danau limboto. diperlukan green belt dan area konservasi untuk mengurangi dampak sedimentasi ke danau limboto. Adapun saluran utama pada dalam tapak yakni sungai biyonga dengan lebar 14 meter Sungai Biyonga berpotensial untuk dimanfaatkan sebagai konservasi zona sepanjang sempadan saluran irigasi yang dapat dimanfaatkan sebagai zona keragaman flora, edukasi dan agrowisata. Saluran Irigasi sekunder di sepanjang jalan batudaa mengalir ke arah pintu air tampodu

Menurut sejarah geologi, Danau Limboto terbentuk sekitar 2 juta tahun silam. Sebelum terbentuk, Dataran Interior Paguyaman-Limboto itu berupa laut. Danau yang terbentuk tadinya adalah sebuah kaldera dari gunung api yang meletus ribuan tahun lalu. Selain itu, proses tektonik yang terus aktif membuat kawasan danau itu terangkat.Berdasarkan data dari Bappeda Provinsi Gorontalo, jenis tanah di sub-DAS Payunga adalah aluvial,latosol, dan podsolik. Ketebalan tanah di sub-DAS payunga cukup bervariasi antara $0,5 \mathrm{~m}-10 \mathrm{~m}$ dengan dominansi ketebalan kurang dari 2. Tanah podzolik memiliki karakteristik kesuburan sedang, bercirikan warna merah atau kuning, memiliki tekstur yang lempung atau berpasir, memiliki $\mathrm{pH}$ rendah, serta memiliki kandungan unsur aluminum dan besi yang tinggi. tanah podzolik merupakan tanah yang tergolong tidak subur baik itu secara fisik maupun kimianya. . Pondasi Tiang pada Tanah Lunak merupakan solusiya dengan memperbesar ukuran pondasi atau memperbaiki kondisi tanah lunak tersebut (dengan proses elektrokinetik untuk menurunkan kadar air tanah). Secara umum rentang tahun 2000-2009 kecenderungan suhu di kawasan ini adalah naik. Kecenderungan suhu yang tinggi memberikan potensi ancaman yang serius bagi organisme ekosistem Danau Limboto, karena akan menimbulkan suhu permukaan air yang tinggi pula

Berikut adalah tabel penggunaan lahan di sub-DAS Payunga Limboto

Penggunaan lahan di sub-DAS Payunga

\begin{tabular}{cc} 
Jenis Penggunaan Lahan & Luasan (ha) \\
\hline $\begin{array}{c}\text { Pertanian lahan kering dan } \\
\text { semak }\end{array}$ & 2241,32 \\
Hutan & 186,45 \\
\hline
\end{tabular}

\begin{tabular}{cc}
\hline Semak/belukar & 346,03 \\
Rawa & 54,81 \\
Permukiman & 238,76 \\
Badan air & 2428,3 \\
Lahan terbuka/ rumput & 1697,72 \\
\hline Total & 4765,09 \\
\hline
\end{tabular}

Sumber: Analisis berdasarkan data Bappeda Provinsi Gorontalo

Berdasarkan Tabel di atas, penggunaan lahan seharusnya di dominasi oleh hutan, bukan pertanian lahan kering karena sub-DAS Payunga berada pada bagian hilir DAS Limboto . Dengan kriteria kawasan seperti itu seharusnya sebagian besar area di Sub-DAS Payunga merupakan kawasan yang dilindungi. Pembukaan hutan sering kali terjadi untuk dikonversi menjadi ladang tanaman hortikultura. Konversi hutan ini menimbulkan berbagai dampak negatif, seperti bencana tanah longsor dan keberadaan flora dan fauna yang semakin sedikit. Hal ini merupakan salah satu akibat ketimpangan pengelolaan lahan kering karena pertambahan jumlah penduduk, terutama akibat perkembangan dan perluasan Kota Limboto, Isimu, dan Kota Telaga sehingga mendorong petani untuk mengusahakan lahan kering berlereng di sub-DAS hulu yang rentan terhadap erosi(Idjudin dan Marwanto 2008). Menurut Whitten et al. (1999), upaya rehabilitasi tidak hanya melalui tindakan-tindakan mekanis seperti pembuatan teras, tetapi juga dengan pengelolaan vegetasi. Vegetasi hutan merupakan bentuk terbaik perlindungan terhadap kehilangan tanah (erosi dan longsor), pengurangan volume air run off dan banjir karena sangat berperan dalam peresapan air dan pemeliharaan stabilitas lereng. Penghijauan dianggap perlu karena adanya penggunaan lahan yang tidak tepat yang menyebabkan penurunan mutu lahan sedemikian rupa.

Danau Limboto merupakan habitat yang sering dikunjungi oleh burung- burung migran yang melakukan perjalanan jarak jauh antar benua. Burungburung ini merupakan burung-burung air yang secara musiman melaksanakan perjalanan panjang. Menjelang musim dingin di belahan bumi utara, burung-burung ini mulai bermigrasi ke selatan menuju daerah yang hangat. Perjalanan jauh itu bisa dimulai dari pantai di Cina di utara sampai ke Australia di selatan. Sebaliknya bila musim dingin di belahan bumi selatan, maka burung-burung ini kembali bermigrasi ke utara melintasi Indonesia. Oleh sebab itu banyak danau-danau di Indonesia merupakan tempat persinggahan burung-burung migran ini untuk 
beristirahat mencari makan sebelum meneruskan perjalanan panjangnya. Di Danau Limboto, tercatat sebanyak 13 spesies burung migran yang sering berkunjung. Burung migran ini menjadi salah satu indikator keseimbangan ekosistem danau karena ketersedian habitatnya menjadi faktor penentu burung migran untuk kembali melintasi daerah danau.

Penataan ruang kawasan pada sub-DAS Payunga akan lebih dititikberatkan kepada upaya memelihara dan meningkatkan kualitas ruang melalui peningkatan kelestarian dan keseimbangan lingkungan. Berdasarkan RTRW Provinsi Gorontalo dan Kajian Lingkungan Hidup Strategis 2012 Provinsi Gorontalo, danau limboto meliputi kawasan:

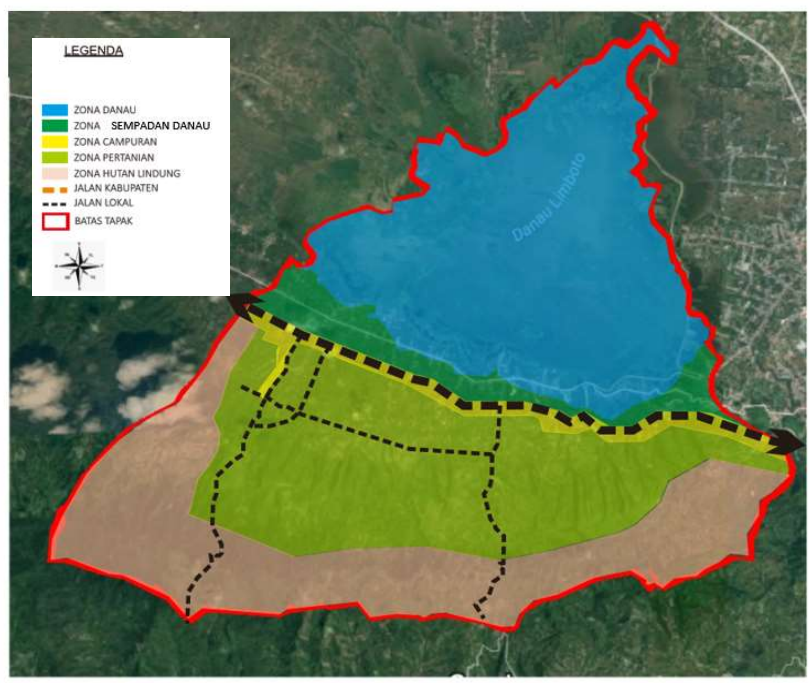

1.kawasan perlindungan kawasan bawahannya: hutan lindung dan area resapan air,

2.kawasan perlindungan setempat: sempadan sungai dan mata air, dan

Tingkat kesesuaian agak sesuai karena kerawanan bencana longsor yang tergolong sedang, akan dijadikan kawasan budidaya secara terbatas. Berdasarkan RTRW Provinsi Gorontalo dan Permen PU No. 22/PRT/M/2007, pada kawasan budi daya subDAS Payunga dapat dibangun hutan produksi terbatas, wisata, dan pertanian semusim.

Syarat dari pembangunan ini dibuat oleh pemerintah daerah. Persyaratan tersebut antara lain meliputi:

a.pembangunan tetap memerhatikan dan memelihara kelestarian lingkungan,

b.pemilihan vegetasi dan pola tanam yang tepat, c.jenis wisata yang dapat dikembangkan adalah wisata alam seperti pendakian gunung, dan tracking tepian danau

d.terdapat rekayasa teknik perkuatan kestabilan lereng, dan sistem drainase yang tepat.

Konsep ruang perencanaan lanskap Kawasan Wisata Danau Limboto dalam bentuk waterfront city didasarkan hasil sintesis, yakni kawasan konservasi dan kawasan budidaya. Kawasan lindung dimaksudkan untuk kawasan hutan serta sempadan sungai dan danau. Kawasan budidaya terdiri dari blok permukiman, blok pertanian, blok konservasi dan blok komersial. Pemilihan lokasi blok juga didasarkan aspek aksesibilitas dan keberadaan sungai. Penjelasan mengenai setiap blok sebagai berikut:

1. blok permukiman terdiri dari zona permukiman warga dan servis publik. Ilustrasi pola tata permukiman dapat dilihat pada Gambar 23.

2. blok komersial yang dimaksud adalah perdagangan barang dan jasa.

3. blok konservasi yakni penghijauan pada bagian hulu diinterpretasikan dari kawasan lindung yang mana terdiri atas kawasan dengan peruntukan hutan dan hilir pada garis sempadan danau.

4. blok pertanian terdiri dari pertanian dalam bentuk sawah dan ladang yang merupakan pertanian semusim seperti jagung.

Gambar 2 pembagian zonasi pada sub-DAS Payunga

Konsep Pengembangan yang dipilih yakni ABC memuat tiga hal mendasar dalam perencanaan yakni Active, Beauty, and Clean Water. Active yang dimaksud adalah dampak yang dirasakan oleh masyarakat baik penduduk sekitar maupun pengunjung dimana pada kawasan sub-DAS payunga bisa memenuhi aktifitas masyarakat yang aktif dalam suatu perencanaan yang berkelanjutan. Beauty disini bukan hanya mengarah terhadap estetika tanaman tetapi sebagai suatu pengalaman visual yang berbeda karena danau limboto memiliki karakter tersendiri. Penggunaan tanaman etnobotani gorontalo di sekitar pemukiman warga serta pengembalian fungsi hutan lindung yang akan membawa kembali habitat burung migran dan satwa danau tentunya diharapkan akan menambah nilai visual panorama. Clean Water diharapkan menjadi suatu solusi untuk pelestarian danau limboto dengan kembali menaturalisasikan dari hulu ke hilir sehingga bisa menekan laju run off dan sedimentasi ke arah badan air danau limboto. 


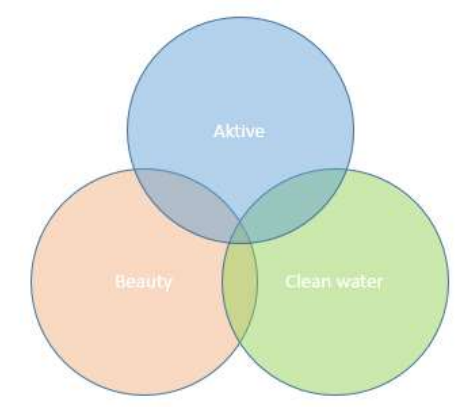

Gambar 3 Konsep Pengembangan ABC Waterfront

Tata letak fisik fasilitas dan kegiatan pada kawasan mencerminkan konservasi sumber daya alam secara sadar dengan pengelolaan kawasan alami yang mendominasi tema pembangunan: $\mathrm{ABC}$ Waterfront untuk penggunaan umum dengan cara menyediakan pengalaman Interaksi terhadap danau. Pembangunan akan mengikuti tema atau karakter desain yang dipilih untuk memastikan proses alami yang sedang berjalan dari basis sumber daya, menggunakan vegetasi yang berasal dari lokasi dan mendukung habitat bagi banyak satwa.

\section{SIMPULAN}

Kondisi Danau Limboto sendiri saat ini termasuk dalam 15 danau kritis di Indonesia.Sub-DAS Payunga merupakan salah satu Sub-DAS yang memiliki masalah sedimentasi terbesar diantara Sub-DAS Lainnya. Oleh karena itu Upaya Pelestarian Kawasan Wisata Danau Limboto sangat diperlukan guna mendukung aspek keberlanjutannya sebagai salah satu kawasan wisata atau destinasi wisata yang ada di Provinsi Gorontalo.

ABC Waterfront pada Sub-DAS payunga merupakan suatu gagasan untuk merehabilitasi suatu kawasan dengan pendekatan konservasi tanah dan air serta pelestarian flora dan fauna . konsep ini akan memberikan suatu bentuk rehabilitasi dengan persentase yang signifikan pada daerah yang memiliki perubahan siklus ekologi yang tinggi dengan pilihan penggunaan pertanian yang akan menghasilkan komunitas satwa liar, bahan pangan, dan habitat.

\section{DAFTAR PUSTAKA}

Pustaka yang berupa majalah/jurnal ilmiah:

Ismaun, I. 2008. Landscape Sustainability dan Perkembangan Prospektif Lanskap Perkotaan. Jurnal Arsitektur Lanskap 2:1-10.

Johan, S. D. 1996. Danau Sebagai Embung Peresap dan Penampung Air Pada Keadaan Banjir. Bogor: Fakultas Matematika dan Ilmu Pengetahuan Alam IPB.

Muhammad. 2006. Pengelolaan Bersama Berbasis Masyarakat Dalam Penataan Dan Pengembangan Kawasan Sungai Siak sebagai Waterfront City. [Tesis]. Sekolah Pasca Sarjana Institut Pertanian Bogor. Bogor.

\section{Pustaka yang berupa judul buku:}

Boon, P.J., P. Calow, and G.E. Petts. 1992. River Conservation and Management. John Wiley \& Sons.

Gomez, J. E. A. 2008. Waterfront Design Withaout Policy? The Actual Uses of Manila's Baywalk. Cities: International Journal of Urban Policy and Planning Vol.24 No. 4, p. 86-106.

Gospodini, A. 2001. Urban Waterfront Redevelopment in Greek Cities. Cities: International Journal of Urban Policy and Planning Vol.18 No. 5, p. $285-295$

Gold S. M. 1980. Recreation Planning and Design. The McGraw-Hill Companies, Inc. USA.

Johan, S. D. 1996. Danau Sebagai Embung Peresap dan Penampung Air Pada Keadaan Banjir. Bogor: Fakultas Matematika dan Ilmu Pengetahuan Alam IPB.

Kodatie, R.J., dan R. Syarief. 2010. Tata Ruang Air. Penerbit Andi. Yogyakarta.

Marsh, W. M. 1997. Landscape planning environmental application. Third edition. United State of America.

Nemerow, N.L. 1991. Stream, Lake, Estuary and Ocean Pollution. Van Nostrand.

Irwan, Zoer'aini Djamal. 1997. Tantangan lingkungan dan lanskap hutan kota. Jakarta: Bumi Aksara

Lynch, Kevin. 1960. The Image of The City. Cambridge : The MIT Press Massachusette

Peraturan Menteri. 2015. Peraturan Menteri Pekerjaan Umum dan Perumahan Rakyat Republik Indonesia No 28 Tahun 2015. 